\title{
Quantification of litter in different genotypes of Eucalyptus in São Gabriel, RS, Brazil
}

\author{
Cuantificación de hojarasca en diferentes genotipos \\ de Eucalyptus en São Gabriel, Rs, Brasil
}

\author{
Kristiana Fiorentin dos Santos ${ }^{*}$, Aline Aparecida Ludvichak², Túlio Barroso Queiroz, \\ Dione Richer Momolli², Claudinei Garlet ${ }^{2}$, Mauro Valdir Schumacher ${ }^{2}$, Elias Frank de Araújo ${ }^{4}$
}

\begin{abstract}
This study aimed to evaluate the litter production of different genotypes of Eucalyptus. An experiment was conducted in 43-monthold stands in the municipality of São Gabriel, Rio Grande do Sul, Brazil. For each genotype, a plot of $599.200 \mathrm{~m}$ was set. Fifteen samples were collected at random in each plot. The accumulated litter production ranged from 2.03 to $4.70 \mathrm{Mg} \mathrm{ha}^{-1}$. This number is the lowest value found in the Eucalyptus dunnii stands and the highest value in the hybrid Eucalyptus urograndis stands. The leaf fraction reached, on average, between $60 \%$ and $91 \%$ of the total litter. The various genotypes had differences in the litter deposited onto the soil top.
\end{abstract}

Keywords: Clones de Eucalyptus. Nutrient cycling. Organic matter. Sustainability.

\section{RESUMEN}

Este estudio tuvo como objetivo evaluar la producción de hojarasca de diferentes genotipos de eucalipto. Se realizó un experimento en stands de 43 meses en el municipio de São Gabriel, Rio Grande do Sul, Brasil. Para cada genotipo, se estableció una parcela de 599.200 m. Quince muestras fueron recolectadas al azar en cada parcela. La producción de hojarasca acumulada varió de 2.03 a $4.70 \mathrm{Mg} \mathrm{ha}^{-1}$. Este es el valor más bajo encontrado en los rodales de Eucalyptus dunnii y el valor más alto en los rodales híbridos de Eucalyptus urograndis. La fracción foliar alcanzó en promedio entre $60 \%$ y $91 \%$ del total de la hojarasca. Los diversos genotipos tuvieron diferencias en la basura depositada sobre la superficie del suelo.

Palabras clave: Clones de eucalipto. Ciclo de nutrientes. Materia orgánica. Sustentabilidad.

\section{Introduction}

Trees play an important role in forest ecosystems; they add organic matter to the soil via deposition of litter and renewal of the root system. Trees also influence the physical attributes of the soil. Forests affect nutrient cycling and soil fertility and promote a microclimate favorable for the existence of numerous organisms (Cunha Neto et al., 2013).

Litter production is the first stage of nutrient and energy transfer from vegetation to the soil. Most nutrients absorbed by the plants return to the forest floor as litter or leaf deposition
(Caldeira et al., 2008). Thus, the study of the nutrient cycle via litter production is fundamental for understanding forest structure and function. Deposited litter in these habitats is reused in the nutrient cycle of the ecosystem. After the litter decomposition, the released minerals are later reabsorbed by the plant roots. The importance of this cycle, connecting the living biological community and its environment, is evidenced in forests that still remain in areas with low fertility soils (Schumacher et al., 2003).

Plant litter is fundamental for forest sustainability. It protects the soil (Cunha Neto

\footnotetext{
Universidade Regional de Blumenau, Blumenau, Santa Catarina, Brasil.

Universidade Federal de Santa Maria, Santa Maria, Rio Grande do Sul, Brasil.

Bracell Bahia Florestal LTDA, Alagoinhas, Bahia, Brasil

Celulose Riograndense, Guaíba, Rio Grande do Sul, Brasil

Corresponding Author: kristianafiorentin@gmail.com
}

Fecha de Recepción: 6 de Febrero, 2020.

Fecha de Aceptación: 12 de Diciembre, 2020. 
et al., 2013) and is a highly desired forest component in areas with degraded soils (Brun et al., 2013). It also reduces the possible negative effect that forest harvesting may cause (Schumacher et al., 2003). The litter consists mainly of leaves (Viera and Schumacher, 2010; Schumacher et al., 2013; Barbosa et al., 2017), which is the component returning the highest amount of nutrients back into the soil (Selle, 2007; Viera and Schumacher, 2010; Corrêa et al., 2013; Viera et al., 2014).

Several factors affect the residue amount that falls from the aerial part of the plants. The litter type depends on the climate, soil, genetic characteristics of the species, age, and planting density (Kolm, 2001). Litter deposition is higher in the period of significant physiological activity of the plants. It causes an intensification of foliage exchange and senescent material release, thus, leading to regrowth of new, more photosynthetically active foliage (Schumacher et al., 2003).

According to Brun et al. (2013), understanding litter deposition from different species and provenances of Eucalyptus sp. allows comparisons and further studies in the field of nutrient cycling. It is fundamentally important to maintaining sustainable management of the soil and mineral resources in a way that does not compromise the nutritional support capacity of the soil. Maintaining the balanced production of direct and indirect benefits of these forests is also crucial.

The present study aimed to evaluate the litter of different genotypes of Eucalyptus from 43-monthold plantations, growing in the city of São Gabriel, Rio Grande do Sul (RS), Brazil.

\section{Materials and methods}

\section{Characterization of the area}

The study was conducted within an area belonging to the Company Celulose Riograndense - CMPC. This area is located in Horto Florestal Batovi within the municipality of São Gabriel, Rio Grande do Sul (RS), Brazil (Figure 1). The geographic coordinates are $30^{\circ} 26^{\prime} 51.68^{\prime \prime} \mathrm{S}$ and $54^{\circ} 32^{\prime} 25.89^{\prime \prime} \mathrm{W}$, with an altitude of $154 \mathrm{~m}$.

According to Köppen, the climate is $\mathrm{Cfa}$ (humid subtropical). The mean temperature is $18.5^{\circ} \mathrm{C}$, and the average annual rainfall reaches 1,355 mm (Figure 2) (Alvares et al., 2013). The soil in the area was classified as a typical Luvisol Haptic Otic. Table 1 shows the percentage of clay and the chemical attributes of the soil for depths from 0 to $110 \mathrm{~cm}$.

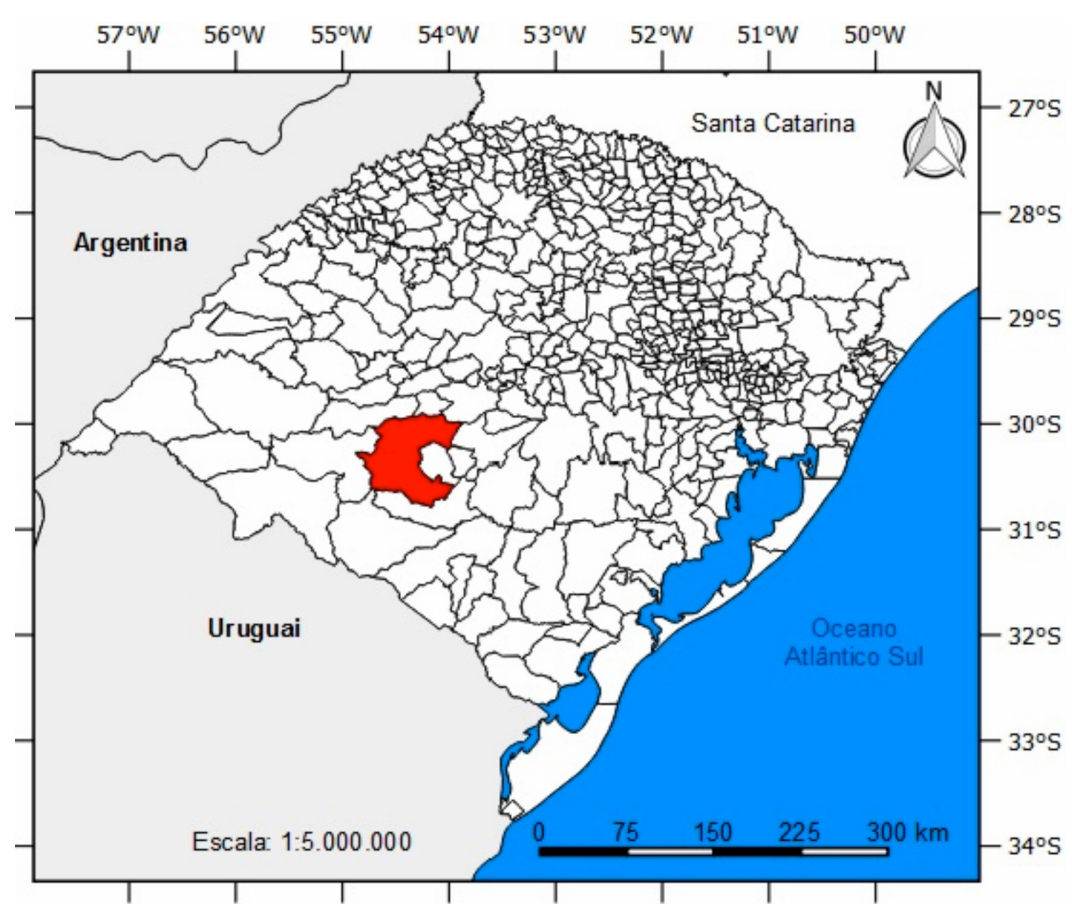

Figure 1. Location of the municipality of São Gabriel, Rio Grande do Sul, Brazil. 


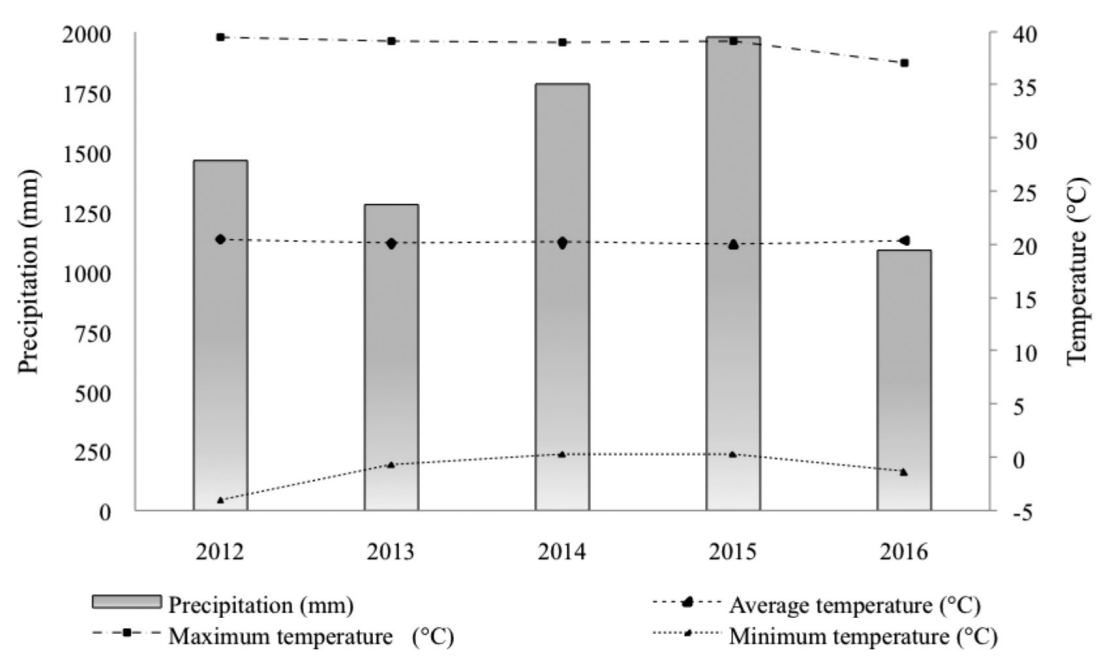

Figure 2. Climatic diagram of the municipality of São Gabriel, RS, Brazil during the study period.

Table 1. Clay and chemical attributes of the soil in the area planted with different 43-month-old genotypes of Eucalyptus in São Gabriel, RS, Brazil.

\begin{tabular}{cccccccccc}
\hline \multirow{2}{*}{ Depht } & Clay & O.C & $\mathrm{V}$ & $\mathrm{m}$ & $\mathrm{Al}$ & $\mathrm{T}$ & $\mathrm{pH}$ & $\mathrm{N}$ & $\mathrm{P}$ \\
\cline { 2 - 9 } & \multicolumn{7}{c}{$\%$} & \multicolumn{7}{c}{$\mathrm{cmol}_{\mathrm{c}} \mathrm{dm}^{-3}$} & $\mathrm{H}_{2} \mathrm{O}$ & $\%$ & $\mathrm{mg} \mathrm{g}^{-1}$ \\
\hline $0-40$ & 4 & 1.65 & 53 & 24 & 1.7 & 10.5 & 5.0 & 0.15 & 3.7 \\
$40-60$ & 23 & 0.94 & 65 & 26 & 4.3 & 21.6 & 5.3 & 0.11 & 2.0 \\
$60-85$ & 14 & 0.51 & 89 & 5 & 1.0 & 28.9 & 5.8 & 0.07 & 1.5 \\
$85-110$ & 4 & 0.17 & 96 & 0 & 0.0 & 29.9 & 6.8 & 0.03 & 1.2 \\
\hline \multirow{2}{*}{ Depht } & $\mathrm{K}$ & $\mathrm{Ca}$ & $\mathrm{Mg}$ & $\mathrm{S}$ & $\mathrm{B}$ & $\mathrm{Zn}$ & $\mathrm{Mn}$ & $\mathrm{Cu}$ & $\mathrm{Fe}$ \\
\hline \multirow{2}{*}{$0-40$} & 0.06 & 3.7 & 1.5 & 13.1 & 0.5 & 0.6 & 4 & 1.2 & 0.2 \\
$40-60$ & 0.16 & 10.3 & 3.3 & 9.8 & 0.5 & 0.5 & 2 & 1.2 & 0.1 \\
$60-85$ & 0.23 & 17.7 & 6.0 & 8.9 & 0.5 & 0.5 & 4 & 1.0 & 0.1 \\
$85-110$ & 0.18 & 20.3 & 6.1 & 6.4 & 0.3 & 0.3 & 4 & 0.5 & 0.1 \\
\hline
\end{tabular}

O.M: organic matter, digestion by wet combustion $\left(\mathrm{K}_{2} \mathrm{Cr}_{2} \mathrm{O}_{7}+\mathrm{H}_{2} \mathrm{SO}_{4}\right)$; V: base saturation; m: aluminum saturation; $\mathrm{pH}$ in $\mathrm{H}_{2} \mathrm{O}$ (1:1); T: $\mathrm{pH} 7$ cation exchange capacity; $\mathrm{Al}, \mathrm{Ca}$, and $\mathrm{Mg}$ exchangeable, solution extraction $\mathrm{KCl}\left(1 \mathrm{~mol} \mathrm{~L}^{-1}\right)$; $\mathrm{P}$ available and $\mathrm{K}$ exchangeable, extracted with Mehlich ${ }^{-1} ; \mathrm{S}$, by solution of $\mathrm{Ca}\left(\mathrm{H}_{2} \mathrm{PO}_{4}\right) 2$ the $500 \mathrm{mg} \mathrm{P} \mathrm{L}^{-1}$.

\section{Planting of the experimental area}

Before the tree planting, the soil was cultivated, limed with $2 \mathrm{Mg} \mathrm{ha}^{-1}$ of limestone, subsoiled down to $50 \mathrm{~cm}$, and set up with ridges ( $40 \mathrm{~cm}$ high). During the plantation, $200 \mathrm{~kg} \mathrm{ha}^{-1}$ of single superphosphate in the form of $\mathrm{N}-\mathrm{P}_{2} \mathrm{O}_{5}-\mathrm{K}_{2} \mathrm{O}$ (06:30:06) + Zn was applied to the groove at a rate of $100 \mathrm{~g} \mathrm{plant}^{-1}$. Subsequently, two post-planting fertilizations in the form of $150 \mathrm{~kg} \mathrm{ha}^{-1}$ of $\mathrm{N}-\mathrm{P}_{2} \mathrm{O}_{5}-\mathrm{K}_{2} \mathrm{O}(12: 00: 20)+$ $0.5 \% \mathrm{~B}$ and $150 \mathrm{~kg} \mathrm{ha}^{-1}$ of $\mathrm{N}-\mathrm{P}_{2} \mathrm{O}_{5}-\mathrm{K}_{2} \mathrm{O}$ (24:00:26) were performed in the sixth and ninth month, respectively.

\section{Implanted Genotypes}

Planting was happened in November 2012, with a spacing of $3.50 \mathrm{~m} \times 2.14 \mathrm{~m}$ presenting an initial density of 1,335 trees per ha. The following Eucalyptus clones were planted: E. benthamii (P1), E. benthamii (P2), E. saligna, E. dunnii, hybrid of E. urophylla $\mathrm{x}$ E. globulus (E. uroglobulus), and 
hybrid of E. urophylla x E. grandis (E. urograndis). E. benthamii (P1) is a provenance originated from Guarapuava, Paraná, Brazil and E. benthamii (P2) originates from Telêmaco Borba, Paraná, Brazil.

\section{Sampling and determination of accumulated litter}

A plot of $599.200 \mathrm{~m}^{2}$ was set for each genotype. Fifteen random samples were collected from each plot, totaling 90 samples as a whole. The litter collection was carried out in June 2016. This was done using an iron frame (Figure 3) of $0.25 \mathrm{~m} \times$ $0.25 \mathrm{~m}\left(0.0625 \mathrm{~m}^{2}\right)$. The frame was placed on the soil's surface, and all organic material inside it was collected and stored in plastic bags. The samples were taken to the laboratory, where they were separated into fractions of the leaves, branches, and miscellaneous (bark, reproductive materials, and non-identifiable residues). The sampled stands were 43 months old.

The samples with the litter fractions were placed in paper containers, then they were dried in a circulation oven and refurbished. This was done at a temperature of $70{ }^{\circ} \mathrm{C}$ until the weight stabilized. Subsequently, the material was weighed on a precision scale $(0.01 \mathrm{~g})$, and the dry weights of the samples were extrapolated to values per hectare.

\section{Statistical analysis}

Using the statistical software Assistat $7.7 \AA$ (Silva and Azevedo, 2009), the data were analyzed using analysis of variance (ANOVA). The averages were compared with the Tukey test, $\mathrm{p} \leq 0.05$.

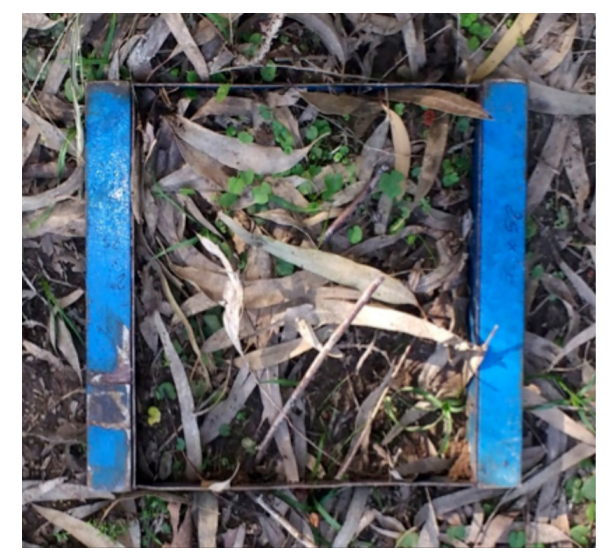

Figure 3. Frame for collecting accumulated litter.

\section{Results and discussion}

The accumulated litter production ranged from 2.03 to $4.70 \mathrm{Mg} \mathrm{ha}^{-1}$ (Table 2). The lowest value was found in $E$. dunnii and the highest in the $E$. urograndis hybrid. Similar results $\left(4.05 \mathrm{Mg} \mathrm{ha}^{-1}\right)$ were found by Witschoreck and Schumacher (2003) in a two-year stand of Eucalyptus spp. in the city of Vera Cruz, RS, Brazil. Santos et al. (2014) obtained higher values (12.76 and $12.00 \mathrm{Mg} \mathrm{ha}^{-1}$ ) in an experiment with four and five-year stands of E. saligna in São Gabriel, RS, Brazil. Brun et al. (2013) documented even higher results $\left(19.5 \mathrm{Mg} \mathrm{ha}^{-1}\right)$ for a 5.5-years old plantation of $E$. uroglobulus in Eldorado do Sul, RS, Brazil. Lower results $\left(1.56 \mathrm{Mg} \mathrm{ha}^{-1}\right)$ were reported in the study by Barreto et al. (2008) of a hybrid one-year-old E. urograndis in Aracruz, ES, Brazil.

According to Ashagrie and Zech (2013), litter production is influenced mainly by species identity, age, and vegetation composition. In addition, the water regime, climate, site conditions, forest undergrowth, silvicultural management, and canopy ratio are also considered to play a significant role. Still, other important factors might be the rate of decomposition and natural disturbances. For example, forest fires and insect attacks, or human-caused disturbances, such removing litter and crops, could also influence the accumulation of litter (Caldeira, 2007).

E. urograndis hybrid produced $57 \%$ and 23\% more litter than the E. dunnii and E. saligna clones, respectively. According to Schumacher et al. (2002), the comparison of litter accumulation data in eucalypts forests is hampered by different

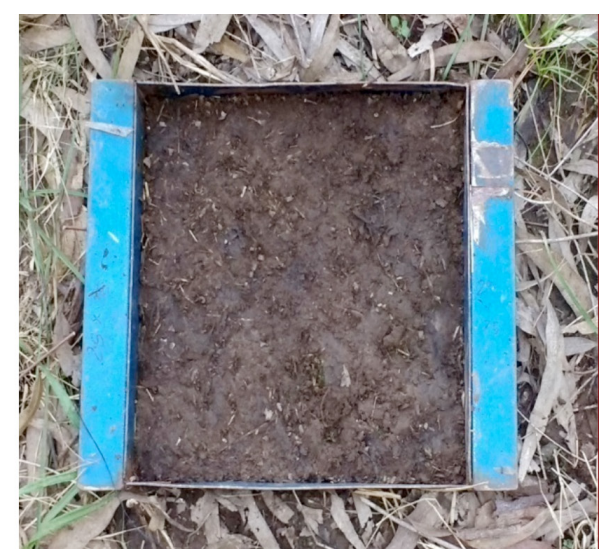


Table 2. Accumulated litter production of 43-month-old Eucalyptus genotypes divided into different components.

\begin{tabular}{|c|c|c|c|c|}
\hline \multirow{2}{*}{ Genotypes } & Leaves & Miscellaneous & Branches & Total \\
\hline & \multicolumn{4}{|c|}{$\left(\mathrm{Mg} \mathrm{ha}^{-1}\right)$} \\
\hline E. benthamii $(\mathrm{P} 1)$ & $\begin{array}{l}2.89 \mathrm{a} \\
(7.5)^{*}\end{array}$ & $\begin{array}{l}0.15 \mathrm{a} \\
(4.1)\end{array}$ & $\begin{array}{l}0.60 \mathrm{~b} \\
(16.4)\end{array}$ & $\begin{array}{l}3.64 \mathrm{a} \\
(100.0)\end{array}$ \\
\hline E. benthamii $(\mathrm{P} 2)$ & $\begin{array}{c}3.63 \mathrm{a} \\
(82.0)\end{array}$ & $\begin{array}{l}0.13 \mathrm{a} \\
(15.3)\end{array}$ & $\begin{array}{l}0.72 \mathrm{ab} \\
(2.7)\end{array}$ & $\begin{array}{l}4.43 \mathrm{a} \\
(100.0)\end{array}$ \\
\hline E. saligna & $\begin{array}{l}3.08 \mathrm{a} \\
(70.0)\end{array}$ & $\begin{array}{l}0.17 \mathrm{a} \\
(4.0)\end{array}$ & $\begin{array}{l}1.20 \mathrm{a} \\
(26.0)\end{array}$ & $\begin{array}{c}4.40 \mathrm{a} \\
(100.0)\end{array}$ \\
\hline E. dunnii & $\begin{array}{l}1.21 \mathrm{~b} \\
(59.7)\end{array}$ & $\begin{array}{l}0.32 \mathrm{a} \\
(15.6)\end{array}$ & $\begin{array}{l}0.50 \mathrm{~b} \\
(24.7)\end{array}$ & $\begin{array}{c}2.03 \mathrm{~b} \\
(100.0)\end{array}$ \\
\hline E. uroglobulus & $\begin{array}{l}3.69 \mathrm{a} \\
(91.0)\end{array}$ & $\begin{array}{l}0.09 \mathrm{a} \\
(2.2)\end{array}$ & $\begin{array}{l}0.37 \mathrm{~b} \\
(6.8)\end{array}$ & $\begin{array}{l}4.05 \mathrm{a} \\
(100.0)\end{array}$ \\
\hline E. urograndis & $\begin{array}{l}3.39 \mathrm{a} \\
(72.1)\end{array}$ & $\begin{array}{l}0.35 \mathrm{a} \\
(7.5)\end{array}$ & $\begin{array}{l}0.96 \mathrm{ab} \\
(20.4)\end{array}$ & $\begin{array}{l}4.70 \mathrm{a} \\
(100.0)\end{array}$ \\
\hline $\mathrm{CV}(\%)$ & 35.02 & 69.76 & 97.68 & 32.6 \\
\hline
\end{tabular}

CV: Coefficient of variation.

Means for each variable in the different treatments followed by equal letters do not show a significant difference (Tukey test, $\mathrm{p} \leq 0.05$ ). ${ }^{*}$ Values in parentheses refer to the percentage of each component in relation to the total biomass of each genetic material.

site conditions and mainly by different planting densities. Unexpected results can be obtained even if litter deposition and accumulation studies are performed in age sequences.

The leaf fraction had the highest yield in all evaluated genotypes, corresponding on average between $60 \%$ and $91 \%$ of the total litter (E. dunnii and E. uroglobulus, respectively). Other studies also found higher percentages of leaves in the deposited material (Fernandes et al., 2006; Soares et al., 2008; Cunha Neto et al., 2013).

The leaves usually constitute the largest proportion of the residue biomass that falls onto the soil. This proportion increases with age to a certain extent and then decreases due to the increased shedding of branches and bark (Reis and Barros, 1990).

E. saligna produced the most amounts of branches that reached $1.2 \mathrm{Mg} \mathrm{ha}^{-1}$. The lowest amounts were measured for E. uroglobulus $\left(0.37 \mathrm{Mg} \mathrm{ha}^{-1}\right)$. Our results showed values similar to those found by Brun et al. (2013). The authors reported a branch quantity of $1.06 \mathrm{Mg} \mathrm{ha}^{-1}$ for 5.5-years old E. uroglobulus plantation. The miscellaneous fraction amount varied from 0.12 to $0.35 \mathrm{Mg} \mathrm{ha}^{-1}$. The lowest value was measured for the E. uroglobulus hybrid and the highest value for the E. urograndis hybrid (0.12 and $0.35 \mathrm{Mg} \mathrm{ha}^{-1}$, respectively).

According to Brun et al. (2013), the accumulation of litter on the ground tends to vary according to the tree growth in the site; however, this may differ from species to species, from hybrid to hybrid, or from clone to clone according to the soil and climate conditions of the planting site. These factors influence the variation of litter accumulation on the forest floor and the time required for its decomposition (Viera et al., 2013).

\section{Conclusion}

The different genotypes showed differences in the accumulation of litter onto the soil. E. dunnii was the species with the least accumulation of litter biomass.

In all genotypes studied, the leaf fraction contributed most to the total amount of litter.

\section{Acknowledgements}

The company Celulose Riograndense- CMPC. 


\section{Literatura citada}

Alvares, C.A.; Stape, J.L.; Sentelhas, P.C.; Gonçalves, J.L.M.; Sparovek, G.

2013. Köppen's climate classification map for Brazil. Meteorologische Zeitschrift, 22: 1-18.

Ashagrie, Y.; Zech, W.

2013. Litter production and nutrient cycling in two plantations and a Podocarpus falcatus dominated natural forest ecosystems in southeastern highlands of Ethiopia. African Journal of Agricultural Research, 8: 4810-4818.

Barbosa, V.; Barreto-Garcia, P.; Gama-Rodrigues, E.; Paula, A. 2017. Biomassa, carbono e nitrogênio na serapilheira acumulada de florestas plantadas e nativa. Floresta $e$ Ambiente, 24: e20150243.

Barreto, P.A.B.; Gama-Rodrigues, E.F.; Gama-Rodrigues, A.C.; Barros, N.F.; Fonseca, S.

2008. Atividade microbiana, carbono e nitrogênio da biomassa microbiana em plantações de eucalipto, em sequência de idades. Revista Brasileira de Ciência do Solo, 32: 611-619.

Brun, E.J.; Ferraz, M.O.; Araújo, E.F.

2013. Relação entre o acúmulo de serapilheira sobre o solo e variáveis dendrométricas em povoamento híbrido de Eucalyptus urophylla $\mathrm{x}$ E. globulus Maidenii, em Eldorado do Sul/RS. Ecologia e Nutrição Florestal, 1: 24-31.

Caldeira, M.V.W.

2007. Quantificação de serapilheira e de nutrientes - Floresta Ombrófila Mista Montana - Paraná. Revista Acadêmica, 5: 101-116.

Caldeira, M.V.W.; Vitorino, M.D.; Schaadt, S.S.; Moraes, E.;

Balbinot, R.

2008. Quantificação de serapilheira e de nutrientes em uma Floresta Ombrófila Densa. Semina: Ciências Agrárias, 29: 53-68

Corrêa, R.S.; Schumacher, M.V.; Momolli, D.R.

2013. Deposição de serapilheira e macronutrientes em povoamento de Eucalyptus dunnii Maiden sobre pastagem natural degradada no Bioma Pampa. Scientia Forestalis, 41: 65-74.

Cunha Neto, F.V.; Leles, P.S.S.; Pereira, M.G.; Bellumath, V.G.H.; Alonso, J.M.

2013. Acúmulo e decomposição da serapilheira em quatro formações florestais. Ciência Florestal, 23: 379-387.

Fernandes, M.M.; Pereira, M.G.; Magalhães, L.M.S.; Cruz,

A.R.; Giácomo, R.G.

2006. Aporte e decomposição de serapilheira em áreas de floresta secundária, plantio de sabiá (Mimosa caesalpiniaefolia Benth.) e andiroba (Carapa guianensis Aubl.) na Flona Mário Xavier, RJ. Ciência Florestal, 16: $163-175$.

Kolm, L.

2001. Ciclagem de nutrientes e variações do microclima em plantações de Eucalyptus grandis Hill ex Maiden manejados através de desbastes progressivos. Escola Superior de Agricultura Luiz de Queiroz.São Paulo, Brazil.
Reis, M.G.F.; Barros, N.F.

1990. Ciclagem de Nutrientes em Plantios de Eucalipto. In: Barros, N.F.; Novais, R.F. Relação solo-eucalipto. Folha de Viçosa. Viçosa, Brazil. pp. 265-302.

Santos, J.C.; Schumacher, M.V.; Witschoreck, R.; Araújo, E.F.; Lopes, V.G.

2014. Nutrientes na serapilheira acumulada em um povoamento de Eucalyptus saligna Smith em São Gabriel, RS. Ecologia e Nutrição Florestal, 2: 1-8.

Schumacher M.V.; Bauermann, G.C.; Copetti, L.; Brun, E.J.; König, F.G.

2002.Fracionamento da serapilheira em três espécies de eucalipto no município de Santa Maria - RS: Eucalyptus urophylla, Eucalyptus cloesiana e Eucalyptus grandis. In: Ciclo de atualização florestal do CONESUL. Santa Maria. pp. 173-180.

Schumacher, M.V.; Brun, E.J.; Rodrigues, L.M.; Santos, E.M. 2003. Retorno de nutrientes via deposição de serapilheira em um povoamento de Acácia no Rio Grande do Sul. Revista Árvore, 27: 791-798.

Schumacher, M.V.; Corrêa, R.S.; Araújo, E.F.

2013. Produção e decomposição de serapilheira em um povoamento de Eucalyptus urophylla $\mathrm{x}$ Eucalyptus globulus. Cerne, 19: 793-800.

Selle, G.L.

2007. Ciclagem de nutrientes em ecossistemas florestais. Bioscience Journal, 23: 29-39.

Silva, F.A.S.; Azevedo, C.A.V.

2009. Principal components analysis in the software assistat statistical attendance. In: Word Congress on Computers in Agriculture 7, RenoNVUSA: American Society of Agricultural and Biological Engineers.

Soares, I.; Queiroz, J.A.; Oliveira, V.H.; Crisóstomo, L.A.; Oliveira, T.S.

2008. Produção de serapilheira e ciclagem de nutrientes na cultura do cajueiro anão precoce. Revista Árvore, 32: 173-181.

Viera, M.; Schumacher, M.V.

2010. Deposição de serapilheira e de macronutrientes em um povoamento de acácia-negra (Acacia mearnsii De Wild.) no Rio Grande do Sul. Ciência Florestal, 20: 225-233.

Viera, M.; Schumacher, M.V.; Caldeira, M.V.W.

2013. Dinâmica de Decomposição e Nutrientes em Plantio de Eucalyptus urophylla $\times$ Eucalyptus globulus no Sul do Brasil. Floresta e Ambiente, 20: 351-360.

Viera, M.; Schumacher, M.V.; Araújo, E.F.; Corrêa, R.S.; Caldeira, M.V.W.

2014. Deposição de serapilheira e nutrientes em plantio de Eucalyptus urophylla x E. globulus. Floresta e Ambiente, 21: 327-338.

Witschoreck, R.; Schumacher, M.V.

2003. Estimativa do carbono da serapilheira em florestas de eucalipto de diferentes idades. In: Congresso Florestal do Estado do Rio Grande do Sul $9^{\circ}$, Nova Prata/RS. Anais... Nova Prata/RS: Congresso Florestal do Estado do Rio Grande do Sul. 